\title{
Communication Skill of the Business Executives: An Empirical Study on Some Local Private Business Concerns in Bangladesh
}

\author{
Nargis Akhter \\ Department of Business Administration, East West University \\ 43 Mohakhali C/A, Dhaka-1212, Bangladesh \\ Tel: +880 2 9882308, 9887989, Ext.- 307, +880 01711807133 \\ E-mail: nargis@ewubd.edu,nargis_252@yahoo.com \\ Sardana Islam Khan \\ Department of Business Administration, East West University \\ 43 Mohakhali C/A, Dhaka-1212, Bangladesh \\ Tel: +8802 9882308, 9887989, Ext. - 105, +880 01711615500 \\ E-mail: saradana@ewubd.edu \\ Md. Kamrul Hassan \\ Department of Business Administration, East West University \\ 43 Mohakhali C/A, Dhaka-1212, Bangladesh \\ Tel: +880 2 9882308, 9887989, Ext. - 160, +880 01711683387 \\ E-mail:kamrul@ewubd.edu
}

\begin{abstract}
The study which is mainly based on primary data attempts to focus on the facts relating to the communication skill of the different levels of business executives of local private business concerns in Bangladesh and their level of awareness regarding the importance of communication skill in their professional career. The study reveals that majority of the executives have positive opinions regarding the importance of communication course designed for executives. Most of the respondents have completed communication course, but majority of them are dissatisfied with it. The study also discloses that many of the executives have received training on communication skill; however majority of them are dissatisfied with course content and quality. Although majority of the executives think that there should be compulsory training program on communication skills in business organizations, still compulsory training programs on communication skill do not exist in any of the respondents' business organizations. Academicians should design and conduct communication courses keeping their application perspectives in view. Moreover employers should arrange compulsory training program on communication skill for their own executives.
\end{abstract}

Keywords: Communication Skill, Training, Communication Course, Business Executive, Local Private Business Concern

\section{Introduction}

Business Executives irrespective of their areas and levels spend much of their working hours to communicate because they get things done by and with people and in getting things done by and with people there is no alternative to communication skill.

It has been estimated that at all organizational levels at least $75 \%$ of each workday is consumed in communication. Today, business executives must have the quality of leadership. Empirical research supports the statement that there is positive correlation between effective leadership and effective communication (Lussier and Achua, 2001).

Our economy is moving from the agro-based economy to industrial economy and the private sector is getting much importance to face the challenges of the global market. Although business executives spend much of their working hours in communication, there is poor knowledge-base regarding the communication skill of our business executives, their level of awareness regarding the importance of communication skill and their levels of satisfaction and 
expectations regarding the training program on communication skill of their organizations.

The researcher tried to address the following specific study issues relating to the communication skill of the business executives of local private business concerns in Bangladesh:

(1) Do the executives think that the communication course is important for the executives?

(2) Did the executives under this study complete communication course?

(3) Did the executives (who have completed communication course) get any help from the communication course?

(4) What benefits have they received from the communication course?

(5) Did the executives get any training on communication skill?

(6) Who organize this training on communication skill?

(7) What are the opinions of the executives towards the training, which they have attended regarding communication skill?

(8) Do the executives think that communication course is important for the executives?

(9) Do the executives think that there should be compulsory communication training program for executives at organization?

\section{Objectives of the Study}

In light of the above-mentioned study issues, the following are the objectives of the study:

(1) to make a knowledge-base regarding the executives' opinions towards the importance of communication course for executives ;

(2) to make a knowledge-base regarding the completion of communication course by executives and their opinions regarding the benefits received by the completion of communication course;

(3) to focus on the executives' training on communication skill and their opinions regarding it;

(4) to determine the different levels of executives' opinions regarding their own communication skill ;

(5) to determine the different levels of executives' opinions regarding the existence of compulsory training program in the organizations on communication skill for executives.

\section{Methodology of the Study}

\subsection{Data Collection}

The study focused on both secondary and primary sources. The secondary sources of data include relevant books and journals. The study collected most of the data from primary source through structured questionnaire. The Likert-type five (05) point's scale was used to know about executives' opinions regarding different relevant study issues. In this five (05) point's scale 5 indicates 'highly satisfactory'/ 'strongly agree'; 4 indicates 'satisfactory'/ 'agree'; 3 indicates 'neither satisfactory nor dissatisfactory'; 2 indicates 'dissatisfactory'/'disagree' and 1 indicates 'highly dissatisfactory'/ 'highly disagree'.

\subsection{Area Surveyed}

The study collected data from Dhaka City because Dhaka is the main centre of the local private business concerns in Bangladesh. Time and cost were other important reasons for this decision.

\subsection{Selection of Sample}

The study selects 10 sample local private business concerns which had production experience for a minimum of 4 years. So, purposive sampling was adopted in selecting sample enterprises. Initially, the study took 250 sample executives belonging to different levels using convenient sampling and among these 250 executives 50 executives were selected from top level, 75 were selected from mid level and the rest 125 were selected from bottom level i.e. from each of the sample enterprise 2, 3 and 5 executives were selected from top, mid and bottom level respectively. After screening finally the study took 200 executives as sample for this study and among these 200 samples 40 belonging to top level, 60 belonging to mid level and the rest belonging to bottom.

\subsection{Analysis of the Data}

The collecting data have been analyzed using percentage, mean and standard deviation.

\section{Literature Review}

Most of the studies conducted on the communication skill of the executives have been reviewed in the following section: 
Bennett and Olney (1986) in "Executives Priorities for Effective Communication in an Information Society" found that executives in selected Fortune 500 companies throughout the United States opined that effective communication skills are more important now than ever before for business success and these skills will remain as a critical component of the information society. The researchers mentioned that the educators should give emphasis on the findings of this research in reviewing and developing realistic business communication curricula.

Papa and Tracy (1988) in "Communicative Indices of Employee Performance with New Technology" found significant positive relationships between each of the communication variables and employee productivity with new technology.

Barker and Others (1992) used a listening effectiveness inventory to measure perceived listening ability among managers who were leaders in a professional management association in the United States and Canada. The study found statistically significant differences for training and gender and insignificant differences were found for age.

Dowd and others (1994) in "What Corporations Seek in MBA Hires: A Survey" conducted a study among MBA candidates and found that $85 \%$ of the recruiters hold communication skill as the most important skill.

Swanson and others (1994) in "Business Communication: A highly valued course in Business Administration" asked 500 undergraduate and graduate students to rank all core business courses and they ranked business communication first among all core courses.

Smeltzer and Thomas (1994) in "Managers as Writers" expressed that managerial writing is performed within a unique context. So, it is important to review the extant research within that context to understand managerial writing.

Moss (1995) in "Perceptions of Communication in the Corporate Community" conducted a study on chief executive officers and directors of personnel or training and the author found that the respondents believe that oral communication before a small group is important and that principles of communication should be stressed over formats for letters and memos and they also believe that reading and editing as well as grammar skills are very important.

Fisher and Ann (1998) in "The High Cost of Living and Not Writing Well" conducted a study among 1000 employers in the United States and showed that Employees must have good communication skill.

Welch and others (1999) in "Communication Change: Ideas from Contemporary Research", researchers summarized the 29 articles and reports to help communicators to change leaders.

Williams and others (1999) in "Key Elements of Effective Supervisor /Employee Communication" found out 21 key principle of Effective supervisor / Employee communication based on comprehensive review of 200 supervisor/employee communication studies.

Clutterbuck (2001) in "Communication Competence and Business Success" mentioned that how the communication differ in successful and less-successful organization. In that study he also examined the link between the communication competence and business success.

Whalen and others (2001) in "How Communication Drives Merger Success" explored the strategy and qualities of mergers companies and offered training tools and diagnostics on the basis of findings.

Roberts and others (2003) in "Intangible Assets and Communication" found the relationship between intangible assets and communication and also suggested analysis and diagnostic tool which can be applied in organizational communication.

Kandath and others (2003) in "Communication Behavior of Virtual Workforces" explored the impact of communication in virtual workforces and observed which communication processes and methods are suitable for virtual workforces.

Bowen (2006) in "The Business of Truth - A Guide to Ethical Communication" mentioned about issues in today's ethical communication. In this article the researchers observed that what type of ethics and frequency the training practitioners receive and their feelings about their role in ethics. They also examined the measurement of their organizations about ethics and their action in conscience of the organization.

Greenwald \& Associates Inc. (2009) in "Survey of Generational Communication Differences around the Globe" identified trends of industrialized countries and emerging economics regarding business communication with diverge age around the world. Researchers addressed that how the expectations and satisfaction of employer's communication and engagement method of Gen Y and Boomers differ in specific areas and also addressed the changes which are needed to improve engagement and teamwork.

Hearn and others (2009) in "Application and implementations of new media in corporate communications: An action research approach" mentioned that advances in new media and web technology are making it easier for organizations, their employees and other concerned members to participate in the creation and management of content . So, it is very much helpful to understand how a corporate communication strategy can leverage these trends.

Bakar and others (2009) in "LMX quality, supervisory communication and team-oriented commitment: A multilevel 
analysis approach", documented the impact of dyadic communication and relationships on individual behavior in workgroups, in this study communication remains as the background element in leadership and management literature as opposed to being the primary process in leader-member relationships development.

Gilsdorf in "Executives' and Academics' Perceptions on the Need for Instruction in Written Persuasion" surveyed communication executives and business communication teachers and expressed that probably business communication classes don't prepare students adequately for persuasive writing.

The above review of the studies conducted on communication skill of business executives reveal that business executives think that effective communication skill is important for the success of business and academicians should offer realistic business communication course curricula. It is also clear from the above review of the studies that not a single study has been conducted on the communication skill of the business executives of Bangladesh. So, it is worthwhile to conduct a study on communication skill of the business executives of Bangladesh.

\section{Findings of the Study}

\subsection{Opinions towards the Importance of Communication Course}

The table 01 reveals that majority $(97.30 \%)$ of the executives' opinion is positive regarding the importance of communication course for the executives. The table 01 also reveals that although a very few percentage of the mid and low level executives think that communication course is not important for the executives but none of the top level executives agree with this opinion.

The Table 02 shows that executives belonging to different levels have completed communication course and their number is more $(58.11 \%)$ than that of executives who did not $(41.89 \%)$ complete the communication course.

The table 03 shows that among those executives who have completed communication course (58.11\%) majority $(90.70 \%)$ of them informed that they have been not benefited by the communication course. The table 03 also reveals that majority of the executives belonging to the three different levels have not been benefited by the communication course.

\subsection{Design and execution of the Communication Course}

A question was asked to those executives who have completed communication course but think that they did not receive any benefit from the completion of communication course. The question was, whether they think that the communication course was not designed and executed from the practical point of view. All of them opined that their course was neither designed nor executed from the practical point of view. Academicians should give emphasis on this comment in designing communication course.

\subsection{Training on Communication Skill}

The table 04 reveals that the number of executives $(52.70 \%)$ who received training is more than that of the executives who $(47.30 \%)$ did not receive training. The table also reveals that among different levels of executives the top management is in highest position $(58.33 \%)$ and the lower level management $(47.22 \%)$ in the lowest position in receiving training.

\subsection{Organizer of the Training on Communication Skill}

The table 05 shows that in case of the majority $(61.53 \%)$ of the executives training program has been arranged by the organization.

\subsection{Opinions towards the quality of the training program on Communication Skill}

The table 06 shows the mean scores (with standard deviations) of the executives' opinions towards the quality of the training program on communication skill. The mean scores of top, mid and bottom level executives' degree of satisfaction reveal that they are dissatisfied with most of the different areas of the communication skill of the training program except for the non-verbal skill regarding which they are neither satisfied nor dissatisfied.

\subsection{Degree of Satisfaction regarding the Executives' Own Communication Skill}

The table 07 shows the mean scores (with standard deviations) of the executives' opinions towards their own communication skill. The mean scores of top, mid and lower level executives' degree of satisfaction regarding oral area of their own communication skill are 4.12, 4.11 and 3.93(near about 4) respectively. So, the top, mid and lower level executives are satisfied with their oral communication skill. It is clear from the mean scores of the top, mid and lower level executives' degrees of satisfaction regarding writing and listening skill that all of them are satisfied with their writing and listening skill. The table 07 shows that the mean scores of the top, mid and bottom level executives' degrees of satisfaction regarding their non-verbal communication skill are 3.44, 3.97 and 3.72 respectively and in each of these three levels the mean scores are near about 4. So, the top, mid and bottom level executives are satisfied regarding their non-verbal communication skill also. Further, the aggregate mean scores show that the executives 
irrespective of their levels are satisfied with their oral, writing and listening communication skill. The aggregate mean score of the executives' degree of satisfaction regarding their non-verbal communication skill is 3.76 which is near about 4. So, the executives irrespective of their levels are satisfied with their non-verbal communication skill also. This question was asked to find out perception regarding their own communication skill and does not necessarily reflect the real picture.

\subsection{Opinions regarding the Compulsory Training Program on Communication Skill}

The table 08 reveals that majority (91.89\%) of the executives think that there should be compulsory training program on communication skill for the executives. The table 08 also reveals that although a very few percentage of the mid and low level executives do not think that there should be compulsory training program in the organizations on communication skill but all the executives belonging to top-level think that there should be compulsory training program on communication skill.

\subsection{Existence of the Compulsory Training Program on Communication Skill}

The study found that compulsory training program on communication skill does not exist in any of the organizations.

\section{Conclusions}

The study revealed that majority of the executives of local private business concerns in Bangladesh thinks that both course on communication and communication skills are important for them and their professional delivery and career success. The study found that the number of executives (belonging to different managerial levels of local private business concerns in Bangladesh) who have completed communication course is greater than those executives who did not complete such course. This is a very positive sign for the local private concerns in Bangladesh because there is little doubt about the significance of communication skill for the executives. However, majority of the executives who have completed communication course expressed dissatisfaction and informed that they have not been benefited from completing communication course. There is no dearth of doubt that although the effectiveness of communication course might vary, but there will be an impact of course completion on participants' communication skill.

All the executives who are not satisfied with communication course think that the course contents of the communication course are not targeted to practical usage or application. The academicians who design such courses should consider this feedback seriously. Like communication course completed by the executives, the researchers found negative information regarding the number of executives who received training on communication skill. The study revealed that majority of the executive training on communication skill was conducted by the organization. The executives are not satisfied with the oral, writing and listening areas and they are neither satisfied nor dissatisfied with the non-verbal areas of the training program on communication skill. However, the executives are satisfied with their own skill on different areas of communication. This may be their wrong perception about their communication skill. The study found that although majority of the executives suggested that there should be compulsory training program on communication skill for business executives, there is no such training program in any one of the sample organizations under survey. The employers of the local private business concerns should consider this matter seriously and take initiative in the right direction.

The study can be helpful for the employers of the local private business concerns in Bangladesh to know about their executives' expectations regarding the relevant issues of communication skill that they need to possess for efficient delivery of their work. The study can also be helpful for the relevant academicians in developing their insight and awareness in designing and conducting communication course integrating the practical usage of such skills in professional job delivery and career success. Findings of this research can initiate conduction of further research to find out the relationship between executives' communication skill and their job performance and also the importance of cultural influences and adaptation in developing course content and conduction of training. Based on this research a comparative study may also be carried out between the executives of local private business concerns and those of multinational business enterprises operating in Bangladesh.

\section{References}

Bakar, Hasan Abu, Mustaffa, Vhe Su. \& Mohamad, Bahtiar. (2009). this is emerald insight online journal, [online]Available:http://www.emeraldinsight.com/Insight/viewContentItem.do;jsessionid=05C7E28B3F0C38A23BCE9 1914986D89D? contentType $=$ Article \& contentId=1769079.

Barkar, Randloph, T. and others. (1992). "An investigation of perceived managerial listening ability”, Journal of Business and Technical Communication, Vol. 6 (4). 438-457.

Bennett, James, C. and Olney, Robert, J. (1986). "Executive priorities for effective communication in an information society”, Journal of Business Communication, Vol. 23 (2). 13-22.

Bowen, Shannon, Ph. D. (2006). this is International Association of Business Communication (IABC). Available: http://www.iabc.com/rf/reports.htm. 
Clutterbuck, David. (2001). this is International Association of Business Communication, Available: http://www.iabc.com/rf/reports.htm.

Dowd, Karen O. and Liedtka, Jeanne. (Winter 1994). "What Corporations Seek in MBA Hires: A Survey", Vol. 10 (2). 34-39.

Fisher, Ann. (December 7, 1998). The High Cost of Living and Not Writing Well. Fortune, 244.

Gilsdorf, Jeanette, W. (1986). "Executives' and academics' perceptions on the need for instruction in written persuasion", Journal of Business Communication, Vol. 23(2). 55-68.

Greenwald, Mathew \& Associates Inc. (2009). this is International Association of Business Communication, Available: http://www.iabc.com/rf/reports.htm.

Hearn, Greg, Foth, Marcus. \& Gray, Heather. (2009). Available: $\mathrm{http}: / /$ www.emeraldinsight.com/Insight/viewContentItem.do;jsessionid=05C7E28B3F0C38A23BCE91914986D89D?co ntentType $=$ Article \& contentId $=1769081$.

http://iabcstore.com/IABCRFRpts/generations.htm.

$\mathrm{http}: / /$ www.emeraldinsight.com/Insight/viewContainer.do? containerType=Journal\&containerId=11210.

http://www.iabc.com/rf/reports.htm.

Kandath, Krishna P., Ph. D., Oetzel, John, Ph. D., Rogers, M. Everett, Ph. D. and Guell, Ann, Ph. D. (2003). this is International Association of Business Communication, Available: http://www.iabc.com/rf/reports.htm.

Lesikar Raymond, V. and Flately Marie, E. (2002). "Basic Business Communication”, New Delhi, Tata McGraw-Hill Publishing Company Limited.

Moss, Frederick, K. (1995). "Perceptions of communication in the corporate community", Journal of Business and Technical Communication, Vol. 9 (1). 63-76.

Papa, Michael, J. and Tracy Karen. (1988). "Communicative indices of employee performance with new technology", Communication Research, Vol. 15 (5). 524-544.

Roberts, Hanno, Ph. D., Bronn, Simcic Peggy, Ph. D. and Breuing, Karl Joachim, Norwegian School of Management. (2003). this is International Association of Business Communication, Available: http://www.iabc.com/rf/reports.htm.

Swanson and Others. (1994). "Business Communications: A highly valued core course in business administration", Journal of Education for Business, 237.

Welch, Nancy \& Goldstein, Mark. (1999). this is International Association of Business Communication, Available: http://www.iabc.com/rf/reports.htm.

Whalen, T. Patricia, Ph. D. and APR. (2001). this is International Association of Business Communication, Available: http://www.iabc.com/rf/reports.htm.

Williams, Linda \& Dong, Qingwen. (1999). this is International Association of Business Communication, Available: http://www.iabc.com/rf/reports.htm.

Table 1. Opinions towards the Importance of Communication Course

\begin{tabular}{|c|c|c|c|c|}
\hline Response & Top & Mid & Low & Total \\
\hline Yes & $100 \%$ & $96.15 \%$ & $97.22 \%$ & $97.30 \%$ \\
\hline No & - & $3.85 \%$ & $12.78 \%$ & $2.70 \%$ \\
\hline
\end{tabular}

Source: Field Survey, 2008

Table 2. Completion of Communication Course at Undergraduate/Graduate Level

\begin{tabular}{|c|c|c|c|c|}
\hline Response & \multicolumn{3}{|c|}{ Levels of Executives } & \multirow{2}{*}{ Total } \\
\hline & Top & Mid & Low & \\
\hline Yes & $58.33 \%$ & $61.54 \%$ & $55.56 \%$ & $58.11 \%$ \\
\hline No & $41.67 \%$ & $38.46 \%$ & $44.44 \%$ & $41.89 \%$ \\
\hline
\end{tabular}

Source: Field Survey, 2008 
Table 3. Benefits Received from the Communication Course

\begin{tabular}{|c|c|c|c|c|}
\hline Response & \multicolumn{3}{|c|}{ Levels of Executives } & \multirow{2}{*}{ Total } \\
\hline & Top & Mid & Low & \\
\hline Yes & $9.09 \%$ & $12.50 \%$ & $6.25 \%$ & $9.30 \%$ \\
\hline No & $90.91 \%$ & $87.50 \%$ & $93.75 \%$ & $90.70 \%$ \\
\hline
\end{tabular}

Source: Field Survey, 2008

Table 4. Training on Communication Skill

\begin{tabular}{|c|c|c|c|c|}
\hline Training & Top & Mid & Low & Total \\
\hline Yes & $58.33 \%$ & $51.69 \%$ & $47.22 \%$ & $52.70 \%$ \\
\hline No & $41.67 \%$ & $42.31 \%$ & $52.78 \%$ & $47.30 \%$ \\
\hline
\end{tabular}

Source: Field Survey, 2008

Table 5. Organizer of the Training on Communication Skill

\begin{tabular}{|c|c|c|c|c|}
\hline $\begin{array}{c}\text { Organizer of the } \\
\text { Training }\end{array}$ & Top & Mid & Low & Total \\
\hline Organization & $42.86 \%$ & $53.33 \%$ & $76.47 \%$ & $61.53 \%$ \\
\hline Self & $57.14 \%$ & $46.67 \%$ & $23.53 \%$ & $38.46 \%$ \\
\hline
\end{tabular}

Source: Field Survey, 2008

Table 6. Opinions towards the Quality of the Training Program on Communication Skill

\begin{tabular}{|c|c|c|c|c|c|c|c|c|}
\hline \multirow{2}{*}{ Levels } & \multicolumn{3}{|c|}{ Areas of Communication Skill } \\
\hline & \multicolumn{2}{|c|}{ Oral } & \multicolumn{2}{c|}{ Writing } & \multicolumn{2}{c|}{ Listening } & \multicolumn{2}{c|}{ Non-verbal } \\
\cline { 2 - 11 } & Mean & $\begin{array}{c}\text { Std. } \\
\text { Deviation }\end{array}$ & Mean & $\begin{array}{c}\text { Std. } \\
\text { Deviation }\end{array}$ & Mean & $\begin{array}{c}\text { Std. } \\
\text { Deviation }\end{array}$ & $\begin{array}{c}\text { Mean } \\
\text { Std. } \\
\text { Deviation }\end{array}$ \\
\hline Top & 2.50 & .463 & 2.29 & .488 & 2.14 & .690 & 3.00 & .632 \\
\hline Mid & 2.32 & .894 & 2.14 & .990 & 2.20 & 1.105 & 3.00 & 1.173 \\
\hline Low & 2.33 & .620 & 2.24 & .663 & 2.19 & .681 & 3.00 & .954 \\
\hline Aggregate & 2.24 & .711 & 2.20 & .786 & 2.19 & .848 & 3.00 & .988 \\
\hline
\end{tabular}

Source: Field Survey, 2008

Table 7. Degree of satisfaction regarding the Executives' Own Communication Skill

\begin{tabular}{|c|c|c|c|c|c|c|c|c|}
\hline \multirow{2}{*}{ Levels } & \multicolumn{3}{|c|}{ Areas of Communication Skill } \\
\hline & \multicolumn{2}{|c|}{ Oral } & \multicolumn{2}{c|}{ Writing } & \multicolumn{2}{c|}{ Listening } & \multicolumn{2}{c|}{ Non-verbal } \\
\cline { 2 - 10 } & Mean & $\begin{array}{c}\text { Std. } \\
\text { Deviation }\end{array}$ & Mean & $\begin{array}{c}\text { Std. } \\
\text { Deviation }\end{array}$ & Mean & $\begin{array}{c}\text { Std. } \\
\text { Deviation }\end{array}$ & $\begin{array}{c}\text { Mean } \\
\text { Std. } \\
\text { Deviation }\end{array}$ \\
\hline Top & 4.12 & .993 & 4.28 & .752 & 4.22 & .808 & 3.44 & 1.031 \\
\hline Mid & 4.11 & .900 & 4.08 & .924 & 4.06 & 1.013 & 3.97 & 1.129 \\
\hline Low & 3.93 & .925 & 4.10 & .617 & 4.07 & .677 & 3.72 & .679 \\
\hline Aggregate & 4.03 & .923 & 4.12 & .767 & 4.10 & .830 & 3.76 & .932 \\
\hline
\end{tabular}

Source: Field Survey, 2008

Table 8. Opinions regarding the Compulsory Training Program on Communication Skill

\begin{tabular}{|c|c|c|c|c|}
\hline Response & Top & Mid & Low & Total \\
\hline Yes & $100 \%$ & $88.46 \%$ & $91.67 \%$ & $91.89 \%$ \\
\hline No & - & $11.54 \%$ & $8.33 \%$ & $8.11 \%$ \\
\hline
\end{tabular}

Source: Field Survey, 2008 